\title{
Análisis de la información de responsabilidad social divulgada por entidades financieras en Argentina
}

\author{
Analysis of Social Responsibility Information Disclosed \\ by Financial Entities in Argentina \\ Análise de informações de responsabilidade social divulgadas \\ por entidades financeiras na Argentina \\ Sandra Pastor \\ Facultad de Ciencias Económicas, \\ Universidad Nacional del Centro de \\ la Provincia de Buenos Aires, Argentina \\ E-mail: pastorsandrap@gmail.com

\section{Valeria Perez} \\ Facultad de Ciencias Económicas, \\ Universidad Nacional del Litoral, Argentina \\ E-mail:vperez@fce.unl.edu.ar \\ Pablo Raffaelli \\ Facultad de Ciencias Económicas, \\ Universidad Nacional del Centro de \\ la Provincia de Buenos Aires, Argentina \\ E-mail: raffaellipablo9@gmail.com \\ Mónica Jugon \\ Facultad de Ciencias Económicas, \\ Universidad Nacional del Centro de \\ la Provincia de Buenos Aires, Argentina \\ E-mail: jugon@econ.unicen.edu.ar
}

Fecha de recepción: 23/01/2020 Fecha de aceptación: 01/06/2020

Palabras clave

- divulgación

- información social y ambiental

- entidades financieras

\section{Resumen}

Este trabajo expone el avance de resultados del proyecto de investigación (2017/2019) respecto a la naturaleza y el alcance de la relación entre la Responsabilidad Social (RS) y la información RS divulgada por entidades financieras en Argentina.

Las diversas teorías que estudian la divulgación de información corporativa asumen que, en determinadas circunstancias, las empresas divulgan más información cuando las expectativas de la relación costobeneficio resultan favorables. Sin embargo, existen particularidades de cada organización que influyen en la estrategia de revelación.

Investigaciones preexistentes (Haro del Rosario et al., 2012; González Fernández, 2012; Pérez-Ruiz y Rodríguez del Bosque, 2012), analizaron sobre los determinantes para la divulgación de información RS en entidades financiera en España. 
La metodología aplicada es de carácter descriptivo y, a partir de un enfoque teórico metodológico cualicuantitativo, se analizan reportes de sostenibilidad (cualitativo) y se estudian los determinantes de la divulgación voluntaria de información RS con modelos estadísticos de regresión lineal.

A partir del análisis de la cantidad de información revelada en relación con los determinantes de la divulgación más significativos, podrá observarse el perfil de las organizaciones emisoras de información de RS. Para ello, y, en virtud de las hipótesis planteadas, se utilizó un índice de revelación global (IRG) que se desagrega en los tres aspectos integrantes de la RS: índice de revelación económica (IRE), índice de revelación ambiental (IRA) e índice de revelación social (IRS).

Los resultados obtenidos concuerdan con estudios anteriores (Gamerschlag et al., 2011), mostrando una asociación positiva entre la cantidad de información de RSE divulgada con una mayor visibilidad de la empresa, una estructura de propiedad de los accionistas más dispersa y la auditoria de los informes de RSE, resultando inversa su relación con la rentabilidad.

\section{Abstract}

This work presents the progress of the results of the research project (2017/2019) regarding the nature and scope of the relationship between Social Responsibility (SR) and the SR information disclosed by financial entities in Argentina.

Various theories that study the disclosure of corporate information assume that, in particular circumstances, companies disclose more information when the expectations of the cost-benefit ratio are favorable. However, each organization has special features which have an influence on their disclosure strategies.

Previous research works (Haro del Rosario et al., 2012; González Fernández, 2012; Pérez-Ruiz y Rodríguez del Bosque, 2012) have analyzed the factors which determine the disclosure of SR information in Spanish financial institutions.

The methodology applied is descriptive and, based on a qualitative and quantitative methodological theoretical approach, sustainability reports (qualitative) are analyzed and the factors which determine the voluntary disclosure of SR information are studied, following linear regression statistical models.

Based on the analysis of the amount of information disclosed in relation to the most significant factors which determine the disclosure of information, the profile of the organizations that issue SR information can be observed. In order to do this, and by virtue of the hypotheses proposed,

Keywords

- Disclosure

- Social and environmental information

- Financial entities a global disclosure index was used, which is disaggregated into the three integral aspects of CSR: economic disclosure index, environmental disclosure index and social disclosure index. 
The results obtained are consistent with previous studies (Gamerschlag et al., 2011) and they show a positive relationship between the amount of CSR information disclosed and a greater visibility of the company, a greater variety of shareholders and the audit of CSR reports. On the other hand, its relationship with profitability is inverse.

\section{Resumo}

Este trabalho expõe 0 andamento dos resultados do projeto de pesquisa (2017/2019) a respeito da natureza e 0 alcance da relação entre Responsabilidade Social (RS) e as informações de RS divulgadas por instituições financeiras na Argentina.

As diversas teorias que estudam a divulgação de informações corporativas assumem que, em certas circunstâncias, as empresas divulgam mais informações quando as expectativas da relação custo-benefício são favoráveis. Porém, existem particularidades de cada organização que influem na estratégia de divulgação.

Pesquisas pré-existentes, (Haro del Rosario et al., 2012; González Fernández, 2012; Pérez-Ruiz y Rodríguez del Bosque, 2012), analisam os determinantes para a divulgação de informações sobre RS em instituições financeiras na Espanha.

A metodologia aplicada é de caráter descritivo e, com base em uma abordagem teórica metodológica qualitativa e quantitativa, analisam-se relatórios de sustentabilidade (qualitativos) e estudam-se os determinantes da divulgação voluntária de informações sobre RS com modelos estatísticos de regressão linear.

A partir da análise da quantidade de informações divulgadas em relação aos determinantes mais significativos da divulgação, poderá ser observado o perfil das organizações emisoras de informações sobre RS. Para isso, e, em virtude das hipóteses propostas, foi utilizado um índice de divulgação global (IRG), desagregado nos três aspectos que integram a SR: índice de divulgação econômica (IRE), índice de divulgação ambiental (IRA) e índice de divulgação social (IRS).

Os resultados obtidos são consistentes com estudos anteriores (Gamerschlag et al., 2011), mostrando uma associação positiva entre a quantidade de informações de RSE divulgadas com uma maior visibilidade

Palavras-chave

- Divulgação

- Informação social e ambiental

- Instituições Financeiras da empresa, uma estrutura de propriedade dos acionistas mais dispersa e a auditoria dos relatórios de RSE, resultando inversa sua relação com a rentabilidade 